УДК [821.161.1+821.161.2]

DOI https://doi.org/10.26661/2414-9594-2020-2-25

\title{
«ПРИМИ МОЙ БРАТСКИЙ ПОЦЕЛУЙ» (ТИПОЛОГІЧНІ СХОДЖЕННЯ ПОЕЗІЙ Д. ФАЛЬКІВСЬКОГО ТА М. ГУМІЛЬОВА)
}

\author{
Крижановська О. О. \\ кандидат філологічних наук, дочент, \\ доиент кафедри світової літератури та російського мовознавства \\ Луганський національний університет імені Тараса Шевченка \\ пл. Гоголя, 1, Старобільськ, Луганська область, Украӥна \\ orcid.org/0000-0001-9840-270X \\ overnik16@gmail.com
}

\author{
Ключові слова: гуманізм, \\ ліричний герой, поезії, \\ типологічні сходження, \\ світогляд.
}

\begin{abstract}
У статті 3'ясовано, що схожий життєвий досвід М. Гумільова та Д. Фальківського сприяв появі таких поезій, які демонструють типологічну близькість авторів. Поети були учасниками Першої світової (М. Гумільов) та громадянської (Д. Фальківський) війн, революційних подій, були свідками численних людських страждань, на собі відчули жахи руйнації старого світу. Багато творів українського поета репрезентують його досвід участі у чекістських розправах 1920-1923 рр. у лавах Надзвичайної Комісії Білорусії. М. Гумільов займав протилежну до Д. Фальківського ідеологічну позицію. У серпні 1921 р. російського поета було розстріляно за участь у контрреволюційній змові. М. Гумільов в одному з останніх творів «Заблукалий трамвай» створює образ ката, який забере його життя. У статті з'ясовано, що у творах Д. Фальківського із циклу «Минуле» представлено сповідь ліричного героя-чекіста, котрого бентежить каяття перед тими, кого він стратив. Автор статті довела, що герой, якого відтворено у творі Д. Фальківського «А він стояв тоді понуро», має багато спільного з особистістю М. Гумільова. Російський поет так само, як і герой згаданої поезії, достойно прийняв смерть і попросив перед стратою докурити. Ситуацію, яку відтворює Д. Фальківський, можна змоделювати як таку, що передає почуття й тих чекістів, які стратили М. Гумільова. Типологічну близькість виявляють поезії Д. Фальківського «В степу коса збиває роси» та «Війна» М. Гумільова. Образ женця в цих творах виступає одним зі складників метафоричного втілення не тільки війни, але й взагалі насильства. У творі російського поета «Війна» воїнижнивці, вбиваючи, виконують свою буденну роботу. У цьому тексті велике значення має релігійно-філософський план, який сприяє ствердженню авторський ідеї гуманізму, поет закликає воїнів бути братами своїм ворогам. Ця думка є провідною й у творах Д. Фальківського, у яких на перший план виходить каяття ліричного героя-чекіста. Почуття провини перед його жертвами зумовлюється авторським гуманізмом, безмежною любов'ю до людини, через яку він за вимушених обставин переступає, зраджуючи власну душу.
\end{abstract}




\title{
"RECEIVE THIS KISS FROM A FRIEND" (TYPOLOGICAL CONVERGENCES OF POEMS BY D. FALKIVSKY AND N. GUMILEV)
}

\author{
Kryzhanovska O. O. \\ Ph.D. in Philological Sciences, \\ Associate Professor at the Department of World Literature and Russian Linguistics \\ Luhansk Taras Shevchenko National University \\ Gogol sq., 1, Starobilsk, Luhansk Region, Ukraine \\ orcid.org/0000-0001-9840-270X \\ overnik16@gmail.com
}

Key words: humanism, lyrical hero, poetry, typological ascents, worldview.
The article reveals that the similar life experience of N. Gumilev and D. Falkivsky contributed to the emergence of such poems that demonstrate the typological similarity of the authors. The poets were participants in the First World War (N. Gumilev) and the Civil War (D. Falkivsky), revolutionary events, witnessed numerous human sufferings, and felt the horrors of the destruction of the old world. Many works of the Ukrainian poet reproduce his experience of participation in the Chekist massacres of 1920-1923 in the ranks of the Extraordinary Commission of Belarus. N. Gumilev took the opposite ideological position to D. Falkivsky. In August 1921, N. Gumilev was shot for participating in a counter-revolutionary conspiracy. N. Gumilev in one of his last works "Lost Tram" creates the image of an executioner who will take his life. The article reveals that D. Falkivsky's works from the "Past" cycle present the confession of a lyrical Chekist hero who is confused by remorse, because he is the executioner who executed such personalities as N. Gumilev and many others. The author of the article proved that the hero, who is recreated in the work of D. Falkivsky "And he stood then gloomily", has much in common with the personality of N. Gumilev. The Russian poet, as well as the hero of the mentioned poetry, accepted death with dignity and asked to smoke before the execution. The author of the article proved that the situation recreated by D. Falkivsky can be modeled as conveying the feelings of those Chekists who executed N. Gumilev. The article clarifies that the typological similarity is revealed by the poems of D. Falkivsky "In the steppe the scythe knocks down the dew" and "War" by N. Gumilev. The image of the reaper in these works is one of the components of the allegorical depiction not only of war but also of violence in general. In the work of the Russian poet "War", the reapers perform their daily work by killing other people. In this text the religious and philosophical basis is of great importance. It helps to understand the author's idea of humanism, the poet urges soldiers to be brothers to their enemies. This idea is leading in the works of D. Falkivsky, in which the repentance of the lyrical hero, who is Chekist, comes to the fore. The feeling of guilt towards his victims is conditioned by the author's humanism, boundless love for the person. The author violates his own principles under forced circumstances, betraying his own soul.
Творчість митців літературної групи «Ланка»-МАРС привертає увагу сучасного літературознавства. Художній досвід Є. Плужника, В. Підмогильного, Т. Осьмачки, Б. Антоненко-Давидовича, Г. Косинки розглянуто в багатьох наукових розвідках. Незважаючи на те, що поезії «ланчанина» Д. Фальківського є однією $з$ яскравих сторінок історії української літератури, його творчість все ще залишається поза увагою науковців. Загальну характеристику творчості митця представлено у дослідженнях Ю. Коваліва та В. Дмитренко. Водночас сьогодні існує нагальна потреба у детальному вивченні художньої спадщини Д. Фальківського, у дослідженні типологічних сходжень і генетичних зв'язків його поезій зі світовою літературою та із творчістю окремих 
митців. На нашу думку, на увагу заслуговує вивчення типологічних сходжень поезій Д. Фальківського та М. Гумільова, яке дозволить побачити спільність і своєрідність художніх пошуків митців. Все це зумовлює актуальність нашої статті, мета якої полягає у вивченні типологічних сходжень творів поетів.

Долі та схожий життєвий досвід Д. Фальківського та М. Гумільова сприяли появі таких поезій, що демонструють типологічну близькість авторів. Значна частина їхнього життя припала на перші роки XX ст. Поети були учасниками Першої світової (М. Гумільов) і Громадянської (Д. Фальківський) війн, революційних подій, були свідками численних людських страждань, на собі відчули жахи руйнації старого світу.

Багато творів українського поета відтворюють його досвід участі у чекістських розправах 1920-1923 рр. у лавах Надзвичайної Комісії Білорусії (поезії з циклу «Минуле», збірки «На пожарищі»). Д. Фальківський ніколи не приховував цих сторінок життя, хоча «уникав у розповідях спинятися над цим докладно» [1, с. 211]. Ліричний герой цих поезій, на думку В. Дмитренко, «роздвоєна, самотня особистість, змушена вибирати між моральними цінностями, які є важливим складником особистісного " $Я$ ”, та реаліями навколишнього життя. Неможливість віднайти гармонійні стосунки із суспільством призводить до розщеплення психіки. Через спогади ліричний герой відтворює критичні ситуації свого життя, його пам'ять відтворює жахливі картини минулого <..> Особливою драматичністю наповнені твори Д. Фальківського, у яких постає протиборство життя та смерті, найчастіше пов'язане 3 подіями громадянської війни, у яких він брав участь у лавах НКБ» [2]. М. Гумільов займав протилежну до Д. Фальківського ідеологічну позицію. У серпні 1921 р. (саме тоді український поет служив у ЧК) його було розстріляно за участь у контрреволюційній змові. Сам поет, немов відчуваючи власну долю, неодноразово писав про передчасну смерть (поезії «Смерть», «Вибір», «Я і Ви», «Мої читачі»), а в одному з останніх творів «Заблукалий трамвай» створює образ ката, який забере його життя:

В красной рубашке, с лицом, как вымя,

Голову срезал палач и мне,

Она лежала вместе с другими

Здесь, в ящике скользком, на самом дне

$[3$, с. 298].

У творах Д. Фальківського представлено сповідь ліричного героя-чекіста, котрого бентежить каяття перед тими, кого він стратив. Поет відтворював драматичні миті, які не дозволяли йому забути минуле. Він «ставив себе на місце жертви, яка “подумать тільки - душу має!”, пробував гля- нути на світ іï очима, - зазначає Ю. Ковалів. Його совість не знає спокою від тіней колись ним же розстріляних людей <.. > "I в мене ж кров - не як у риби”, - вигукнув Д. Фальківський, але підлеглий дисциплінарного статуту, він, як і ліричний герой, не міг не виконати жорстокого наказу» [4, с. 23]. Каяттям ліричного героя перед своїми жертвами наповнені поезії 3 циклу «Минуле». У творі «А він стояв тоді понуро» автор зображує чоловіка, котрий перед смертю просить у чекіста докурити. Це людина, яка достойно, з покірністю та байдужістю приймає власну смерть:

А він стояв тоді понуро;

І руки зв’ язані іззаду...

I тільки місяць коло муру

Скликав сестер своїх на раду.

В очах байдужість і покора...

I тихо:

- Дайте докурити. -

А ще за мить - лицем у гору [5, с. 50]

Тут доречно привести спогади про те, як повівся М. Гумільов перед стратою. «Смерть поет прийняв гідно, - пише В. Полушин. - Працівник ЧК Дзержібашев (який сам був розстріляний у 1924 р.) відкрито захоплювався мужністю поета на допитах. Таємний інформатор ЧК поет Сергій Бобров розповів Г. Іванову: “Знаєте, шикарно помер. Я чув 3 перших вуст. Посміхався, докурив цигарку <.. > Навіть на хлопців з особливого відділу справив враження <..> Мало хто так помирає» [6]. Тобто ситуацію, яку відтворює Д. Фальківський, можна змоделювати як таку, що передає й почуття тих чекістів, які стратили М. Гумільова:

Тряслися руки...

А за стіною степ широкий.

Пустіть.

Та я ж чекіст...

Ах, муки!.. [5, с. 50]

Б. Антоненко-Давидович у передмові до виданої у Братиславі книги Д. Фальківського «Ранені дні» точно відтворює почуття автора-чекіста під час виконання вироку: «Мусиш убивати невідому тобі людину, провини якої ти сам і не знаєш, але тобі сказано, що то ворог, - i ти мусиш вірити $\mathrm{i}$ вбити... Але ворог, тепер уже безборонний, приречений на страту, - теж людина. Він, як і чекіст $<\ldots>$ має те, що притаманно людині, має душу, яка зараз, після короткого вдару пострілу, покине безвільне мертве тіло» [1, с. 211].

Поезії Д. Фальківського «В степу коса збиває роси» та «Війна» М. Гумільова виявляють типологічну близькість. Образ женця пов'язаний iз метафоричною репрезентацією не тільки війни, але й узагалі насильства. Поезію М. Гумільова «Війна» присвячено подіям Першої світової війни, у якій поет брав добровільну участь. Цикл поезій про війну є своєрідним втіленням ідеалів поета. 
Саме за жорстких і страшних умов війни повною мірою змогла проявитися його сила духу. «Війна, пише Ю. Зобнін, - була в очах Гумільова своєрідним очисним вогнем $<\ldots>$ витягає справжню, первісно-невинну людську душу, з якої він увійде в “оновлений світ”. На думку Гумільова, під кулями $<$...> людина знаходить всю велич і радість свого існування, відчуває справжню цінність простих людських почуттів: кохання, ненависті, дружби, скорботи» [7]. Під час війни М. Гумільов двічі був нагороджений Георгіївським хрестом і Орденом Святого Станіслава. Військові події стали основою для багатьох його поезій, які викликають протилежну оцінку дослідників. Одні бачать у них творчість наївного «співака війни». «Звичайно, в роки Першої світової війни, - пише А. Давидсон, все ж були люди, які бачили події більш тверезо і мудро, ніж Гумільов <...> Нагадаю слова, сказані мені про нього Анною Андріївною Ахматовою: “Який він політик? Наївна була людина". До того ж - а можливо, в цьому і криється головне пояснення - він з дитинства звик бачити в собі воїна» [8, с. 195]. Інші дослідники звертають увагу на те, що Перша світова війна для поета уособлює християнські цінності, що є важливою складовою частиною авторського світогляду. Сучасник М. Гумільова Г. Чулков підкреслював: «Нелицемірно сприймають війну як таку, війну як “лицарське і благородне" діло, а не як необхідне, але завжди жахливе зло, лише люди такого душевного ладу, який зовсім не співзвучний новому життю, нової культурі, новій релігійній свідомості. Гумільов один з них. Він навіть не підозрює можливість рефлексії в справі війни <..> Тут щирість, твердість, безпосередність, яким позаздрить, мабуть, і самий переконаний 3 німецьких воїнів $<$... \оезій, присвячених війні, небагато в книгах поета, але до всього в цьому світі він підходить, як воїн, якого на час відпустили з табору, щоб він відпочив» [9, с. 451-452].

У поезії «Війна» поет, поєднуючи побутовий і релігійно-філософський плани, зображує трагічні події війни як звичну працю. Воїни це женці, «подвиг сеющие и славу жнущие» на полях битв, де гавкає собака-кулемет і дзижчать бджоли-шрапнелі. Похідне життя поет порівнює із життям мирного села «в самый благостный из вечеров». Війна, смерть, трагедії з'єднуються 3 розумінням обов'язку перед людьми, із почуттям святої, угодної Богові справи. За плечима християнського війська - «серафимы ясны и крылаты», які уособлюють праведність їхньої справи. Сенс життя ліричного героя й авторську світоглядну позицію представлено у фіналі твору. Ці рядки, позбавлені тогочасного ура-патріотичного пафосу, є також проявом християнських переконань М. Гумільова:
Но тому, О Господи, и силы

И победы царской час даруй,

Кто поверженному скажет: «Милый,

Вот, прими мой братский поцелуй!» [3, с. 172]

У поезії Д. Фальківського «В степу коса збиває роси» ліричний герой порівнює свою справу 3 роботою жнивців. На початку твору поет зображує «дівчат із серпами», що «у смерть іграють 3 колосками» [5, с. 43]. Ліричний герой, дивлячись на колос, питає: «Чи думав він, що буде мертвий?». Колосся хліба складається у снопи, які автор називає «безкровними жертвами» [5, с. 43]. Герой співчуває невинним волошкам, яких жнивці не мають часу обминати, він немов заздрить дівчатам, котрі не відчувають болю свого колосся:

Добро дівчатам із серпами:

Їх жертви плакати не вміють...[5, с. 43]

Автор, звертаючись до паралелізму, відтворює почуття ліричного героя, який, немов жнець, мусить косити «в ім'я майбутнього врожаю». Він із жахом розуміє, що:

Жертви душу

- Подумать тільки - душу мають...[5, с. 43]

Волошки у творі уособлюють випадкові жертви, котрі потрапляють під серпи, так само, як i під час кривавих революційних розправ гинуть невинні люди, потрапляючи під кривавий терор:

І стане гірко-гірко в серці:

А може, й тут волошки сині?

Та чи ж побачиш в буйнім герці,

Де винуваті, де невинні? [5, с. 43]

Поет підкреслює, що простота смертельного вироку робить страту буденною, знецінює життя.

А так - усе до болю просто...

Рука пером сім раз чирикне,

І вийде слово просте: «Розстріл».

(Папір німий... мовчить... не крикне).

А потім прийде сіра північ,

І в камері задзвонить тиша...

А там... «Ноган» розбудить півнів...

Земля в крові...

I «він» - не дише [5, с.43].

Отже, творчість А. Фальківського та М. Гумільова виявляє типологічне сходження у створенні образа ката-чекіста й у зображенні женців, які демонструють особливості авторського світогляду. У поезії «Заблукалий трамвай» М. Гумільов, немов передбачаючи власну трагічну долю, створює образ ката, що забере у нього життя. У творі російського поета «Війна» воїни-жнивці, вбиваючи, виконують свою буденну роботу так само, як і ліричний герой-чекіст поезій Д. Фальківського. У цьому тексті велике значення має релігійно-філософський план, який сприяє ствердженню авторський ідеї гуманізму. Підтвердженням цієї думки є фінал поезії, у якому М. Гумільов 
закликає воїнів до милосердя та допомоги переможеним, закликає їх бути братами своїм ворогам. Ця думка $є$ провідною й у творах Д. Фальківського зі циклу «Минуле», у яких на перший план виходить каяття ліричного героя-чекіста. Почуття провини перед його жертвами зумовлюється авторським гуманізмом, безмежною любов'ю до людини, через яку він за вимушених обставин переступає, зраджуючи власну душу. Отже, результати нашої роботи - це тільки перше наближення до вивчення типологічних сходжень творів поетів. Перспективним вважаємо компаративне дослідження інших поезій Д. Фальківського та М. Гумільова.

\section{ЛІТЕРАТУРА}

1. Войноровський Б. Подумать тільки - душу має! Фальківський Д. Ранені дні. Братислава : Словацьке педагогічне товариство; Пряшів : Відділ української літератури, 1969. С. 210-220.

2. Дмитренко В. Основні мотиви творчості Дмитра Фальківського. URL: https: dspace.pdaa.edu.ua > bitstream. (дата звернення 21.10.2020)

3. Гумилёв Н. Сочинения : в 3 т. Т. 1. Москва : Художественная литература, 1991. 590 с.

4. Ковалів Ю. «На перехрещених скрижалях». Фальківський Д. Поезї. Київ : Радянський письменник, 1989. С. $5-26$.

5. Фальківський Д. Поезії. Київ : Радянський письменник, 1989. 175 с.

6. Полушин В. Смерть принял достойно. URL: https://gumilev.ru/biography/24/ (дата звернення 21.10.2020).

7. Зобнин Ю. Стихи Гумилева, посвященные мировой войне 1914-1918 годов (военный цикл). URL: https://gumilev.ru/about/100 (дата звернення 21.10.2020).

8. Давидсон А. Муза странствий Николая Гумилёва. Москва : Наука, 1992. 319 с.

9. Чулков Г. Поэт-воин. Н.С. Гумилёв: pro et contra. Санкт-Петербург : РХГИ, 1995. С. $451-454$.

\section{REFERENCES}

1. Voinorovskyi, B. (1969) Podumat tilky - dushu maie! [Just think - he has a soul!]. Falkivskyi D. Raneni dni. Bratislava: Slovak Pedagogical Society; Presov: Department of Ukrainian Literature. P. 210-220. [in Ukrainian].

2. Dmytrenko, V. Osnovni motyvy tvorchosti Dmytra Falkivskoho [The main motives of Dmytro Falkivsky's work]. URL : https: dspace.pdaa.edu.ua > bitstream. [in Ukrainian].

3. Gumilyov, N. (1991). Sochineniya [Works]. Vol. 1. Moscow: Hudozhestvennaya literatura. [in Russian].

4. Kovaliv, Yu. (1989). Na perekhreshchenykh skryzhaliakh [On crossed tablets]. P. 5-26 [in Ukrainian]. Falkivskyi D. Poezii. Kyiv : Radianskyi pysmennyk.

5. Falkivskyi, D. (1989). Poezii [Poetry]. Kyiv : Radianskyi pysmennyk. [in Ukrainian].

6. Polushin, V. Smert prinyal dostojno [Death accepted with dignity]. URL: https://gumilev.ru/biography/24/ [in Russian].

7. Zobnin, Yu. Stihi Gumileva, posvyashchennye mirovoj vojne 1914-1918 godov (voennyj cikl) [Gumilyov's poems dedicated to the World War 1914-1918 (military cycle)]. URL: https://gumilev.ru/about/100 [in Russian].

8. Davidson, A. (1992) Muza stranstvij Nikolaya Gumilyova [The muse of Nikolai Gumilyov's wanderings]. Moscow : Science. [in Russian].

9. Chulkov, G. (1995) Poet-voin [Poet-warrior]. N.S. Gumilyov : pro et contra. Sankt-Petersburg : RHGI. P. 451-454. [in Russian]. 